\begin{tabular}{|l|l|}
\hline & $\begin{array}{l}\text { Jurnal Bimbingan dan Konseling Ar-Rahman } \\
\text { Volume 4, Nomor 1,Tahun } 2018 \\
\text { Tersedia Online: } \text { http://ojs.uniska.ac.id/index.php/BKA } \\
\text { e-ISSN 2477-6300 }\end{array}$ \\
\hline
\end{tabular}

\title{
KEEFEKTIFAN LAYANAN INFORMASI KARIR BERBANTUAN WEBSITE UNTUK MENINGKATKAN PERENCANAAN KARIR SISWA SMA DI KOTA TARAKAN
}

\author{
Hotma Rosalin Tumanggor, Sunawan, Edy Purwanto \\ Program Studi Bimbingan dan Konseling, Pascasarjana, Universitas Negeri Semarang \\ E-mail: hotmarosalin@yahoo.co.id/085247531113
}

\begin{abstract}
ABSTRAK
Dewasa ini persaingan dunia kerja semakin kompleks dan persaingan kualifikasi persaingan kerja semakin ketat. Siswa diharapkan dapat memiliki perencanaan karir sesuai dengan bakat, minat, taraf intelegensi, dan nilai-nilai kehidupan yang dimiliki untuk memudahkan siswa dalam merencanakan karir. Dalam membuat perencanaan karir, siswa membutuhkan informasi sebagai bahan pertimbangan siswa dalam membuat perencanaan karir yang sesuai dengan bakat, minat, taraf intelegensi dan nilai-nilai kehidupan yang dimilikinya melalui layanan informasi karir. Dengan pemahaman tersebut, siswa mampu merencanakan karirnya secara matang sesuai dengan keadaan dirinya. Upaya meningkatkan perencanaan karir dapat dilakukan dengan menggunakan layanan informasi karir berbantuan website. Penelitian ini bertujuan untuk meningkatkan perencanaan karir siswa SMA di Kota Tarakan melalui layanan informasi karir berbantuan website. Desain eksperimen yang digunakan dalampenelitian ini adalah pre eksperimen dalam bentuk one group pretest-post design.Penelitian ini melibatkan 35 siswa sebagai kelompok eksperimen yang dipilih secara purposive sampling. Hasil penelitian ini adalah layanan informasi karir berbantuan website efektif meningkatkan perencanaan karir siswa SMA di Kota Tarakan $(10,094, \mathrm{p}<0.01)$.
\end{abstract}

Kata Kunci: Layanan Informasi Karir; Website; Perencanaan Karir

\begin{abstract}
Today's increasingly complex business world competition and competition qualifications increasingly tight. Students are expected to have career planning according to their talents, interests, intelligence level, and life values to facilitate students in career planning. In making career planning, students need information as a material balance of students in making career planning in accordance with the talent, interests, intelligence level and the values of life it has through career information services. With that understanding, students are able to plan their careers according to their situation. Efforts to improve career planning can be done using career information services assisted by website. This study aims to improve the career planning of senior high school students in Tarakan City through information career services assistance through the website. The experimental design used in this research is quasi-experiment in the form of one group pretest-post design. The career planning scale consists of 45 items with 5 falling items and 0.875 alpha coefficient. This study involved 35 students as an experimental group selected by purposive sampling. The result of this research indicate that career information service the website-assisted effectively improve the career planning of high school students in Tarakan City $(10,094, p<0.01)$.
\end{abstract}

Keywords: Career Information Service; Website; Career Planning

Dipublikasikan Oleh :

UPT Publikasi dan Pengelolaan Jurnal

Universitas Islam Kalimantan Muhammad Arsyad Al-Banjari Banjarmasin 


\section{PENDAHULUAN}

Karir merupakan suatu proses yang berlangsung seumur hidup, dipilih, dan ditentukan untuk melalui suatu proses dimana tidak hanya mempertimbangkan kekuatan dan kelemahan personal individu, namun memfokuskan pada aspek-aspek ekstrinsik dari kepuasaan dalam memilih pekerjaan seperti uang, status, dan kondisi kerja (Nathan\&Hill, 2012:3). Teori perkembangan Ginzberg (Bruder, 2010) menyebutkan bahwa siswa SMA berada pada tahap tentative dimana siswa harus sudah mampu memikirkan atau merencanakan karier mereka berdasarkan minat dan nilai-nilai atau potensi yang mereka miliki. Perencanaan karir merupakan salah satu aspek yang paling penting dalam perkembangan karir individu. Kecakapan dalam mengambil keputusan merupakan tujuan utama dalam perencanaan karir yang harus ditempuh oleh setiap individu.

Data faktual yang diperoleh dari tiga SMA di Kota Tarakan berdasarkan hasil wawancara dan dokumentasi menjelaskan bahwa $60 \%$ dari siswa masih bingung dalam memilih program studi untuk melanjutkan ke perguruan tinggi, $30 \%$ sudah mengetahui program studi yang hendak mereka pilih, dan $10 \%$ memutuskan untuk bekerja. Selain itu juga, didukung dengan hasil penyebaran alat ungkap masalah (AUM) oleh guru BK kepada seluruh siswa kelas XII. Beberapa siswa membuat rencana karir hanya didasarkan atas kemauan dan keinginan tanpa mempertimbangkan kemampuan yang dimiliki, bahkan terdapat siswa yang menyerahkan pilihan karir pada teman sebaya atau orang lain.

Selain itu, penelitian yang dilakukan oleh Budiamin (2002) di Kabupaten Bandung memaparkan bahwa sebanyak $90 \%$ peserta didik menyatakan masih bingung dalam memilih karir di masa depan dan $70 \%$ peserta didik menyatakan rencana masa depan tergantung pada orang tua (Abavian, 2013). Melihat hal tersebut, penentuan karir yang tepat dan sesuai dengan bakat, minat, taraf intelegensi, dan nilai-nilai kehidupan yang dimiliki oleh siswa perlu direncanakan terlebih dahulu. Perencanaan karir siswa bukan hanya sekedar pekerjaan yang dijabatnya, melainkan suatu pekerjaan yang benar-benar sesuai dengan potensi dirinya. Beberapa siswa merencanakan kariernya secara tidak realistis. Mereka membuat rencana karier hanya didasarkan atas kemauan dan keinginannya tanpa mempertimbangkan kemampuan yang dimiliki.

Berdasarkan dari hasil wawancara dengan guru BK di tiga SMA Tarakan yakni berdasarkan kondisi faktual yang dialami oleh beberapa guru BK di sekolah mengalami hambatan dalam menjalankan layanan yang telah dirancang. Hal ini dikarenakan tidaknya adanya alokasi jam bimbingan dan konseling sehingga adanya keterbatasan dalam memberikan layanan bimbingan dan konseling kepada siswa. Hal ini tentu saja beberapa layanan khususnya dalam layanan informasi karir menjadi tidak optimal sehingga siswa sebagai penerima layanan mengalami kekurangan informasi karir yang seharusnya didapat. Dengan begitu, tentu saja mempengaruhi siswa dalam memahami perencanaan karir secara intensif.

Kemudian, berdasarkan data faktual, $25 \%$ dari siswa enggan untuk datang ke ruang $\mathrm{BK}$ untuk melakukan konseling atau sekedar konsultasi dikarenakan adanya perasaan malu, kesempatan waktu yang terbatas, ruangan yang kurang tepat untuk berkonsultasi, dan tidak terbuka dalam mengungkapkan masalah yang sebenarnya. Beberapa siswa tersebut merasa lebih nyaman untuk konsultasi atau sekedar sharing terkait karir melalui chat whatsapp atau line.

Berdasarkan hasil wawancara dengan guru BK yang menyatakan terdapat beberapa hambatan yang belum dapat ditangani secara maksimal dalam menjalankan tugas yakni : (1) Kebutuhan siswa akan informasi karir yang disertai keinginan yang besar dari siswa namun belum cukup mendapatkan perhatian dikarenakan tugas-tugas tambahan yang diberikan oleh kepala sekolah seperti terlibat dalam kepanitiaan kegiatan sekolah bahkan dipercaya sebagai ketua panitia pada beberapa kegiatan di sekolah dan dimintai untuk mengurusi beasiswa untuk siswa, (2) waktu layanan terbatas, konselor dalam memberikan layanan bimbingan dan konseling khususnya yang berkaitan dengan karir masih belum maksimal sehingga menjadi hal yang wajar jika siswa mengalami kebingungan dalam perencanaan dan penentuan arah karir, dan (3) rasio siswa yang ditangani oleh konselor tidak sesuai sehingga membuat guru BK tidak maksimal dalam melayani kebutuhan siswa.Melihat permasalahan diatas, maka harus ada tindakan untuk menjawab hambatan-hambatan yang ada ke arah yang lebih baik agar pelayanan bimbingan dan konseling dapat berjalan dengan baik bahkan dirasakan kebermanfaatannya bagi siswa.

Mengikuti perkembangan abad 21, guru bimbingan dan konseling atau konselor dituntut memiliki keterampilan bahkan kesiapan diri menghadapi perkembangan teknologi khususnya berkaitan pada layanan bimbingan dan konseling online. Di abad 21, setiap pendidik harus memiliki kompetensi yakni mengintegrasikan teknologi di dalam kehidupan khususnya proses belajar mengajar kepada pendidik (Pineida, 2011; Sumarwiyah dan Zamroni, 2017).

Terlebih lagi, dalam permendikbud nomor 111 tahun 2014 dimana merupakan pedoman yang harus dikuasai oleh setiap guru bimbingan dan konseling di tiap tingkat pendidikan di Indonesia, didalamnya termasuk penguasaan teknologi. Hal ini mengindikasikan bahwa konselor hendaknya 
Hotma Rosalin Tumanggor, Sunawan, Edy Purwanto Jurnal Bimbingan dan Konseling Ar-Rahman Volume 4, Nomor 1, Tahun 2018

e-ISSN 2477-6300

memanfaatkan teknologi untuk memudahkan pemberian layanan. Dengan memakai teknologi, konselor dan siswa dalam hal ini tidak perlu lagi bertatap muka, dengan dibantu teknologi informasi dan komunikasi yang memadai, pemberian layanan bimbingan dan konseling dapat dilakukan jarak jauh, dan dapat dilakukan kapan saja dan dimana saja.

Dari berbagai produk teknologi informasi tersebut, website adalah produk paling menarik, kreatif, dan inovatif bagi siswa karena di dalam sebuah website, siswa akan mendapatkan berbagai informasi yang lengkap dengan tampilan yang kreatif dan inovatif, sehingga akan meningkatkan minat peserta didik, dan media website ini akan sangat cocok diterapkan untuk meningkatkan minat siswa. Penelitian oleh Abisoye, Ganiyu, dan Blessing (2015) mengemukakan bahwa minat siswa yang tinggi terhadap penggunaan website karena siswa dapat dengan mandiri secara online dapat memperoleh berbagai informasi baik informasi pendidikan maupun karir. Siswa dapat mengakses berbagai informasi yang diberikan oleh guru bimbingan dan konseling melalui website. Hal ini senada dengan pernyataan yang dikemukan oleh Van Horn dan Myrick (2001); Setyawan dan Wibowo (2016) mengemukakan bahwa dalam lingkup layanan konseling sekolah teknologi komputer seperti website dapat dimanfaatkan untuk memperoleh berbagai informasi berkaitan berbagai perguruan tinggi, profesi, untuk mengelolah intervensi konseling, untuk membangun relasi dari berbagai kota dan negara, dan untuk menerima pendidikan dan pemantauan. Oleh karena itu, untuk membantu siswa meningkatkan minat, konselor sekolah dituntut untuk bisa membuat layanan informasi karir yang kreatif dan inovatif dengan berbantuan website.

Pelaksanaan layanan informasi karir yang melibatkan bantuan website memungkinkan layanan informasi karir dilaksanakan dengan mudah dan tanpa batas dikarenakan bisa dilaksanakan dimana saja. Sebab dengan bantuan website, akan menjadi lebih inovatif pada pelaksanaan layanan informasi karir agar berjalan lebih optimal. Layanan informasi karir berbantuan website menekankan pada peningkatan perencanaan karir siswa sehingga siswa tahu akan karir yang dipilihnya dan tahu akan pilihan karir yang sesuai bakat, minat, dan taraf intelegensi. Hal ini menjadi landasan bagi peneliti untuk melakukan layanan informasi karir berbantuan website untuk meningkatkan perencanaan karir siswa.

\section{METODE}

Penelitian ini merupakan jenis penelitian kuantitatif yang menguji secara langsung pengaruh suatu variabel yang lain dan menguji hipotesis tentang perbedaan tingkat perencanaan karir sebelum dan sesudah diberikan perlakuan layanan informasi karir berbantuan website. Desain eksperimen yang digunakan dalam penelitian ini adalah pre eksperimen dalam bentuk one group pretest-post design. Partisipan penelitian terdiri dari 35 siswa kelas XII di SMA Negeri 3 Kota Tarakan. Partisipan yang dipilih secara purposive sampling. Adapun desain eksperimen yang digunakan adalah one group pretest-posttest design yang dapat digambarkan sebagai berikut:

Tabel 1. Desain Penelitian

\begin{tabular}{cccc}
\hline Kelompok & $\begin{array}{c}\text { Pre } \\
\text { Test }\end{array}$ & Treatment & $\begin{array}{c}\text { Post } \\
\text { Test }\end{array}$ \\
\hline Eksperimen & $\mathrm{O}_{1}$ & $\mathrm{X}$ & $\mathrm{O}_{2}$ \\
\hline
\end{tabular}

Keterangan:

$\mathrm{O}_{1} \quad$ : Tingkat perencanaan karir pada pre test

$\mathrm{O}_{2}$ : Tingkat perencanaan karir setelah diberikan perlakuan layanan informasi karir berbantuan website.

$\mathrm{X}$ : Perlakuan diberikan selama 8 hari (melalui 1x sesi membaca dan melalui ruang tanya-jawab (layanan komentar) yang tersedia pada website

Teknik pengumpulan data yang digunakan dalam penelitian ini menggunakan alat ukur skala perencanaan karir. Skala perencanaan karir terdiri dari 45 item dengan item gugur 5. Hasil uji instrumen, item skala perencanaan karir dinyatakan valid dengan besaran indeks korelasi $\geq 0.3$ dengan koefisien alpa sebesar 0.875. Data yang didapatkan selanjutnya dianalisis dengan menggunakan $t$-test.

\section{HASIL DAN PEMBAHASAN}

Kondisi perencanaan karir siswa SMA Negeri 3 Kota Tarakan pada kelompok eksperimen pada kategori sedang sebanyak 24 siswa sedangkan untuk kategori rendah sebanyak 11 siswa. Setelah mendapatkan layanan informasi karir berbantuan website, kondisi perencanaan karir siswa meningkat menjadi pada kategori tinggi sebanyak 26 siswa dan kategori sedang sebanyak 9 siswa.

Data kemudian dianalisis dengan menggunakan t-test. Hasil menunjukkan bahwa layanan informasi karir berbantuan website dapat meningkatkan perencanaan karir siswa secara signifikan. Dari keseluruhan skor perencanaan karir siswa mengalami kenaikan. Dari skor pretest dengan mean sebesar 95,69 dan skor posttest sebesar 124,94. Peningkatan skor mean sebesar 29,2 poin atau 30,6\% dipengaruhi oleh treatment layanan informasi karir berbantuan website.

Berdasarkan analisis data hipotesis dengan kriteria $t_{\text {hitung }} \leq \mathrm{t}_{\text {tabel }(1-\alpha)}$ maka uji beda menunjukkan bahwa jumlah $t_{\text {hitung }} \leq \mathrm{t}_{\text {tabel }(1-\alpha)}$ dengan hasil $\mathrm{t}_{\text {hitung: }}$ : 10,094, $\mathrm{p}<0.05$ Hal ini membuktikan dari nilai $\mathrm{t}$ hitung yang lebih besar dari pada $t$ tabel, dan berdasarkan nilai signifikansi yang bernilai lebih besar

Dipublikasikan Oleh :

UPT Publikasi dan Pengelolaan Jurnal

Universitas Islam Kalimantan Muhammad Arsyad Al-Banjari Banjarmasin 
Hotma Rosalin Tumanggor, Sunawan, Edy Purwanto Jurnal Bimbingan dan Konseling Ar-Rahman Volume 4, Nomor 1, Tahun 2018

e-ISSN 2477-6300

atau sama dengan 0.05 sehingga dapat disimpulkan bahwa layanan informasi karirdapat meningkatkan perencanaan karir siswa.

Penelitian ini dimaksudkan untuk menguji efektifitas layanan informasi karir berbantuan website untuk meningkatkan perencanaan karir siswa. Hasil penelitian ini menunjukkan bahwa layanan informasi karir berbantuan website efektif untuk meningkatkan perencanaan karir siswa. Hal ini dibuktikan melalui hasil uji efektivitas yang membuktikan bahwa adanya peningkatan pada skor pre test (assessment awal) dan skor post test (evaluasi akhir). Hasil ini selaras dengan penelitian Abisoye et al (2015) bahwa layanan informasi karir berbantuan website yang diberikan kepada siswa SMP membantu siswa dalam mencari berbagai informasi pendidikan lanjutan yang berkontribusi pada perencanaan karir mereka. Penelitian ini menyajikan kuis karir beserta interpretasinya yang akan mengarahkan siswa SMP kepada perencanaan karir. Dibandingkan dengan temuan Abisoye et al (2015), maka penelitian ini melakukan uji efektivitas layanan informasi karir berbantuan website untuk meningkatkan perencanaan karir siswa SMA di Kota Tarakan. Website bkkarirtarakan.com tidak menyajikan kuis karir namun menyajikan berbagai informasi mengenai perguruan tinggi, menyediakan lembar kerja dan layanan informasi karir khusus bagi pengguna yang ingin memberikan pertanyaan.

Tabel 2. Hasil Uji Analisis Paired

\begin{tabular}{lcc}
\hline & Pengukuran & Skor \\
& & \\
\hline Pretest & M & 95,69 \\
& SD & 16,28 \\
Posttest & M & 124,94 \\
& SD & 10,020 \\
\hline $\mathrm{t}$ & & 10,094 \\
$\mathrm{p}$ & & $.000(<0,01)$ \\
\hline
\end{tabular}

Penilaian kualitas website dibagi menjadi empat antara lain kualitas penggunaan (usabilityquality), kualitas informasi (information quality), kualitas interaksi (interaction quality) dan keseluruhan (over all). Berdasarkan hasil penilaian kualitas produk oleh siswa menunjukkan bahwa produk pada kategori sangat baik. Kualitas website dari sisi kualitas penggunaan, tampilan (halaman website) cukup menarik dengan menyajikan gambar salah satu profesi yaitu "manajemen bisnis" sehingga pengguna memahami bahwa tema website ini berkaitan dengan karir. Website dapat dilihat dalam satu tampilan layar monitor sehingga memudahkan pengguna untuk melihat seluruh tampilan website sekaligus, warna desain tampilan sangat jelas dengan menggunakan mayoritas warna biru muda. Warna biru merupakan warna yang dikaitkan dengan efek emosional positif seperti relaksasi, perasaan menyenangkan, dan meningkatkan daya tarik untuk membeli suatu produk (Nordeborn, 2013).

Selain itu, kecepatan download tampilan (halaman website) cukup cepat, resolusi gambar cukup seimbang, desain grafis disesuaikan dengan jenis website sehingga terlihat menarik, dan gambar sesuai dengan jenis website. Beberapa materi diberikan gambar dan video agar website tidak terlihat monoton. Hasil tersebut menunjukkan bahwa siswa memberikan respon yang baik mengenai mengenai tampilan website www.bkkarirtarakan.com menjadikan siswa tertarik menggunakan website untuk memperoleh informasi terkait perencanaan karir.. Dengan demikian fitur utama pada website yang memberikan kesan yang baik para siswa pada website dalam pemenuhan akan berbagai informasi. Hasil penelitian ini didukung oleh teori yang dikemukakan oleh Flavian et al., (2009) berpendapat bahwa apperance (tampilan website) harus diperhatikan untuk mencapai keberhasilan sebuah website.

Kesan pertama dari tampilan sebuah website menentukan evaluasi pengguna website yang akan mempengaruhi persepsi dan perilaku. Secara khusus, aspek estetika dapat mempengaruhi tingkat kepuasaan pada suatu website. Selain itu, tampilan estetika dari sebuah website dari sebuah website memperlihatkan tingkat kredibilitas suatu website. Hal ini senada dengan penelitian oleh Flavian et all (2011); Chen et al (1999) mengemukakan bahwa tampilan atau desain yang baik dan menarik dapat membangkitkan perasaan senang dan positif sehingga tingkat kegunaan terhadap website yang dirasakan dapat menyebabkan kepuasaan, kepercayaan, dan kesetiaan yang tinggi terhadap situs website tersebut Kemudian penilaian pada sisi kualitas
informasi, konten $\quad \begin{gathered}\text { pada } \\ \text { website }\end{gathered}$ www.bkkarirtarakan.com sangat jelas, informasi relevan dengan kebutuhan siswa yakni informasi mengenai perencanaan karir, setiap materi diperbarui dan terkini khususnya mencantumkan jadwal pelaksanaan pendaftaran berbagai perguruan tinggi negeri, materinya bersumber dari artikel dan berbagai

\section{Dipublikasikan Oleh :}


referensi yang reliabel, memiliki informasi yang benar, menyajikan informasi lengkap mengenai prospek pekerjaan di berbagai fakultas dan ukuran gambar yang disediakan adalah cukup tepat. Konten pada website dikembangkan berdasarkan aspek-aspek perencanaan karir sehingga menjadi pedoman bagi siswa dalam merencanakan karirnya.

McGrawl (2002:4) menyatakan bahwa konten atau isi yang baik dari sebuah website adalah konten yang dapat memenuhi kebutuhan pengguna secara online yang disediakan oleh website dan harus diorganisasikan dengan baik. Dalam hal ini kebutuhan yang dibutuhkan siswa adalah berbagai informasi yang berkaitan dengan perencanaan karir. Kualitas informasi pada website mempengaruhi dalam pengambilan keputusan atau tugas-tugas yang lainnya pada pengguna website. Semakin baik kualitas informasi, akan semakin tepat pula keputusan yang diambil (Istianingsih dan Wiwik, 2009). Glassberg, B.C., Grover \& Teng (2006) mengemukakan bahwa kualitas informasi mempengaruhi komponen afektif (emosi user, perasaan puas/tidak puas, suasana hati, dan evaluasi pengguna seperti suka/tidak suka). Hal ini diperkuat dengan adanya hasil penilaian UCA (understanding, comfort, action) dimana siswa menyatakan bahwa merasa puas, senang, merasa terbantu dan tertarik dengan adanya website bkkarirtarakan.com dikarenakan siswa memperoleh berbagai informasi perguruan tinggi. Hal ini relevan dengan penelitian ini, kualitas informasi website bkkarirtarakan.com terbukti pada kategori sangat baik sehingga membantu siswa meningkatkan perencanaan karirnya.

Selain itu, penilaian dari sisi kualitas interaksi berada pada kategori baik dikarenakan pada website bkkarirtarakan.com tersedia menu "layanan informasi karir khusus" dengan menyertakan e-mail dan nomor kontak bagi siswa untuk menyampaikan pertanyaan ataupun komentar sebagai forum diskusi sehingga mampu menciptakan komunitas yang lebih spesifik melalui adanya layanan informasi karir khusus. Kualitas interaksi dianggap penting di dalam sebuah website karena memfasilitasi komunikasi dua arah dengan para penggunanya (Fan, Lee dan Kim, 2013). Dalam hal ini, forum diskusi melalui menu " layanan informasi karir khusus" memfasilitasi siswa secara mandiri melalui online untuk menyampaikan segala pertanyaannya.

Layanan informasi karir yang diberikan guru BK kepada siswa dapat membantu guru BK dalam memberikan berbagai informasi yang berkaitan dengan perencanaan karir mereka (Abisoye, Ganiyu dan Blessing, 2015). Website digunakan untuk penunjang kinerja konselor dan sebagai media untuk berinteraksi dengan siswa. Website bisa didayagunakan sebagai media bagi sekolah yang tidak memiliki alokasi jam BK dan kapasitas guru BK yang tidak mampu melayani kebutuhan siswa sehingga pelaksanaan layanan informasi karir dapat berjalan optimal. Dari penelitian ini dan yang dilakukan oleh peneliti, website memberikan kemudahan kepada guru BK dalam memberikan berbagai informasi penting berkaitan dengan karir dan dapat berinteraksi dengan siswa tanpa harus bertemu secara tatap muka dengan tetap memperhatikan asas-asas dan kode etik dalam bimbingan dan konseling. Interaksi siswa dengan guru BK terfasilitasi di website bkkarirtarakan.com pada menu layanan informasi karir khusus. Siswa dapat menyampaikan pertanyaan, komentar, atau tanggapan kepada guru BK melalui menu tersebut. Demikian juga siswa, mendapatkan manfaat dengan adanya website ini. Siswa dapat memperoleh informasi-informasi penting bagi perencanaan karir, dapat mengasessmen diri melalui lembar kerja, dan dapat berinteraksi atau berkonsultasi dengan guru BK tanpa harus bertatap muka secara langsung.

Layanan informasi karir berbantuan website untuk meningkatkan perencanaan karir siswa terdiri dari 1 kali sesi membaca dan untuk selanjutnya siswa melakukan online dengan waktu yang fleksibel untuk membaca berbagai informasi yang tersedia pada website bkkarirtarakan.com sesuai dengan kebutuhannya. Namun untuk kepentingan pelayanan kepada siswa, peneliti menyediakan waktu khusus untuk berinteraksi langsung dengan konselor. Pada penelitian ini jadwal online untuk sesi tanya-jawab dilakukan pada pukul 18.00-21.00.

Layanan informasi karir berbantuan website untuk meningkatkan perencanaan karir mempunyai implikasi pada guru BK. Dalam hal ini seharusnya guru BK dapat mendukung sepenuhnya dalam perencanaan karir siswa sesuai dengan kebutuhan siswa khususnya di bidang karir, hal ini didukung dengan pendapat dalam penelitian Witko, Kim et al (2011) menyatakan bahwa kebutuhan karir yang tinggi pada siswa kelas XII yang berkaitan dengan kebutuhan informasi perguruan tinggi dan prospek kerja berimplikasi kepada peran konselor dalam memberikan layanan bantuan berupa pemberian layanan informasi karir dalam membantu meningkatkan perencanaan karir siswa. Siswa membutuhkan informasi, saran, dan arahan dari konselor dalam membantu mereka dalam merencanakan karir. Hasil penelitian ini juga selaras dengan penelitian sebelumnya bahwa siswa dipersiapkan untuk membantu keputusan karir sehingga menekankan kembali akan pentingnya perencanaan karir (Hiebert, 2012). Dengan demikian, guru BK di sekolah sangat relevan dalam mengimplementasikan layanan informasi karir berbantuan website untuk meningkatkan perencanaan karir siswa SMA karena terbukti tingkat efektivitasnya melalui uji coba terbatas. 
Hotma Rosalin Tumanggor, Sunawan, Edy Purwanto Jurnal Bimbingan dan Konseling Ar-Rahman Volume 4, Nomor 1, Tahun 2018 e-ISSN 2477-6300

Selain itu, guru bimbingan dan konseling di sekolah dapat mengimplementasikan layanan informasi karir berbantuan website untuk meningkatkan perencanaan karir siswa khususnya pada sekolah yang tidak memiliki alokasi jam BK karena dapat dilaksanakan tanpa bertemu secara langsung dan tidak terbatas oleh waktu karena dapat dilakukan dimana saja serta pada siswa yang cenderung suka berkomunikasi dengan hubungan teks dan siswa yang merasa tidak nyaman melakukan pelayanan bimbingan dan konseling secara langsung.

Layanan informasi karir berbantuan websitediharapkan dapat mendukung sepenuhnya pada peningkatan perencanaan karir siswa di kota Tarakan serta diharapkan pada peneliti selanjutnya model layanan informasi karir berbantuan website dapat digeneralisasikan ke seluruh siswa SMA yang ada di Indonesia dengan berbagai jenjang dan pelaksanaan model layanan informasi karir berbantuan websitetidak hanya melalui sesi membaca melalui online, namun model layanan informasi karir berbantuan website dapat dilakukan secara klasikal atau dengan menggunakan metode blanded learning.

\section{PENUTUP}

Penelitian ini dilakukan untuk meningkatkan perencanaan karirsiswa SMA kelas XII SMA di Kota Tarakan melalui layanan informasi karir berbantuan website. Hasil penelitan ini menujukkan bahwa layanan informasi karir berbantuan website dapat meningkatkan perencanaan karirsiswa secara signifikan. Hal ini didasarkan pada perolehan nilai pre test dan post test pada skala perencanaan karirsiswa setelah setelah mengikuti layanan informasi karir berbantuan website.

Selanjutnya penting bagi guru BK/Konselor sekolah memahami konsep dasar layanan informasi karir dan media BK berupa website, sebab pelaksanaan layanan informasi karir berbantuan website mengkolaborasi antara layanan informasi karir dan media BK berupa website. Selain itu, diharapkan bagi peneliti selanjutnya untuk menguji layanan informasi karir berbantuan website terhadap variabel lain dan dengan sampel yang berbeda.

\section{REFERENSI}

Abavian, M. (2013). Program Bimbingan Karir untuk Meningkatkan Kemampuan Perencanaan Karir Peserta Didik. Bandung: UPI.

Abisoye, Blessing, dan Ganiyu. (2015). A Web Based Career Guidance Information System for PreTertiary Institution Students in Nigeria. Journal Engineering and Technology, 1(3), 229-240.

Bruder, M.B. (2010). Early Childhood Intervention: A Promise to Children and Families for Their
Future. Exceptional Children, 76(3), 339-355. doi: 10.1177/001440291007600306.

Budiamin, Amin. (2002). Manajemen Layanan Bimbingan Karir pada SMA Negeri di Kabupaten Bandung. Jurnal Psikologi Pendidikan dan Bimbingan Psikopedagogika, 2, 259-266.

Chen, H.,Wigand and Nilan. (1999). Optimal Experience of Web Activities. Journal of Computer in Human Behavior, 15(2), 585-608. doi: 10.1016/S0747-5632(99)00038-2

Fan, Q., Lee, J., \& Kim, J. (2013). The Impact of Web Site Quality on Flow-Related Online Shopping Behaviors in C2C E-Marketplaces: A CrossNational Study. Managing Service Quality, 23(5), 364-387. doi: 10.1108/MSQ-11-20120150

Flavian, Carlos. (2009). Web Design: A Key Factor for the Website Success. Journal of Systems and Information Technology, 11(2), 168-184. doi: 10.1108/1328726091095 5129

Glassberg, B.C., Grover \& Teng. (2006). Information Systems Research with an Attitude. Database for Advances in Information Systems, 37(2), 76-85.

Hiebert B et al. (2012). Needs Assessment for Program Planning and Program Development: a brief review. Alberta Counsellor, 26(1), 1118.

Istianingsih dan Wiwik. (2009). Pengaruh Kepuasan Pengguna Sistem Informasi Terhadap Kinerja Individu. Simposium Nasional Akuntansi XII, $1-70$.

Nathan \& Hill. (2006). Career Counseling. London: Sage Publications Ltd.

Nordeborn. (2013). The Effect of Color in Website Design: Searching for Medical Information Online. Thesis: Lunds University.

Permadi. (2016). Masalah-Masalah yang Dihadapi Peserta Didik dalam Perencanaan Karir dan Implikasinya terhadap Pelayanan Bimbingan Karir. Jurnal Penelitian Bimbingan dan Konseling, 1(2), 134-145.

Pineida, F. O. (2011). Competencies for the 21st Century: Integrating ICT to Life, School and Economical Development.Procedia - Social and Behavioral Sciences. Elsevier B.V., 28, 54-57. doi: 10.1016/j.sbspro.2011.11.011.

Setyawan dan Wibowo. (2016). Pengembangan Model Layanan Informasi Karir Berbantuan Web Tentang Studi Lanjut ke Perguruan Tinggi. Jurnal BK UNNES, 5(1), 29-36.

Sumarwiyah dan Zamroni. (2017). Pemanfaatan Teknologi Informasi (TI) dalam Layanan Bimbingan dan Konseling Sebagai Representasi Berkembangnya Budaya Profesional Konselor Melayani Siswa. Jurnal 
Hotma Rosalin Tumanggor, Sunawan, Edy Purwanto Jurnal Bimbingan dan Konseling Ar-Rahman Volume 4, Nomor 1, Tahun 2018

Bimbingan dan Konseling Ar-Rahman, 2(1), 114.

Ummah, M., \& Sutijono. (2013). Penerapan Layanan Informasi Karir untuk Meningkatkan Kemampuan Perencanaan Karir Siswa Kelas XII SMAN 1 Krembung Sidoarjo. Jurnal BK UNESA, 1(1), 1-11.

Van Horn, S. M., \& Myrick, R. D. (2001). Computer
e-ISSN 2477-6300

Technology and the 21st Century School Counselor. Professional School Counseling, 5(2), 124-130.

Witko, Kerry B Bernes, Kris Magnusson dan Angela D Bardick. (2011). Senior High School Career Planning: What Students Want. Journal of Educational Enquiry, 6(1), 34-49. 